\title{
MACROECONOMIC EFFECTS OF SOCIAL SECURITY PRIVATIZATION IN A SMALL UNIONIZED ECONOMY
}

\author{
ANTONIS ADAM \\ CESIFO WORKING PAPER NO. 1371 \\ CATEgORY 1: Public FinANCE \\ DECEMBER 2004
}

PRESENTED AT THE CESIFO/DELTA CONFERENCE ON STRATEGIES FOR REFORMING

PENSION SCHEMES, NOVEMBER 2004

\footnotetext{
An electronic version of the paper may be downloaded

- from the SSRN website: http://SSRN.com/abstract $=646062$

- from the CESifo website: www.CESifo.de
} 


\title{
MACROECONOMIC EFFECTS OF SOCIAL SECURITY PRIVATIZATION IN A SMALL UNIONIZED ECONOMY
}

\begin{abstract}
This paper analyses the effects of a pension system privatization in a unionized economy. Using an overlapping-generations framework we show that in an environment characterized by unemployment, a reform towards a private pension system in the steady state may result in lower levels of employment and capital stock. In this case even if the privatization increases the welfare of all future generations, the reduction in the welfare of the elderly due to reduced pension benefits may be greater and a Pareto improving transition to a private system may not be feasible. On the other hand if the reform leads to higher employment then a Paretoimproving pension privatization scheme can be constructed.
\end{abstract}

JEL Code: H55, J51, J32.

Keywords: public pensions, social security privatization, labour union, unemployment.

Antonis Adam

Athens University of Economics and Business

Department of International and European

Economic Studies

76 Patission st.

10434 Athens

Greece

aadam@aueb.gr

An earlier version of this paper was presented at the CESifo Conference "Strategies for Reforming Pension Systems". I wish to thank Thomas Moutos, Panos Hatzipanayotou, James McHugh, Spyros Vassilakis, the conference participants and especially my discussant András Simonovits for helpful comments and discussions. The research presented in this paper was financially supported by the Greek Ministry of Education and the European Union under the "Iraklitos" research fellowship program. 


\section{Introduction}

Recent demographic trends in most industrialized countries show that the reduced fertility rates and increased longevity increase significantly the share of the elderly on the population. This aging population problem creates concerns about the feasibility of the Pay- As- You Go (PAYGO) pension arrangements. As the size of the working age generation shrinks relative to the retired population, the recipients of the pension benefits increase whereas the contributors to the system decrease. Then the same level of benefits cannot be sustained unless there is either an increase on the contribution rates or an increase on the retirement age. Adding to this problem, the PAYGO contributions yield consistently lower returns than comparable investments in the capital market and thus they amount to an implicit tax on the young generation. Even though these are by no means new problems they have recently received much attention by economists and policy- makers around the world.

The widespread support for a shift from the public- PAYGO arrangements to private funded pensions usually involves proposals for scaling back the PAYGO pensions and replacing them with private pensions, in the form of mandatory savings or personal social security accounts (World Bank, 1994, Diamond, 1996, Gramlich, 1996). Proponents of such schemes argue that privatizing social security, besides tackling the financial problems of the PAYGO programs, also have positive consequences on the working of the capital market and the growth rate of the economy (Holzman, 1997, Feldstein and Liebman, 2002 for a survey). All these positive externalities that a private system has may help alleviate the double burden borne by the transitional generation.

Usually the effects of social security privatization are examined in intertemporal models of perfect labour markets and full employment. In order to assess the effects of social security privatization in Europe, where unemployment is quite high and labour unions have increased power that affects labour market outcomes, this setting is far from the real world. The issue of social security privatization in an environment characterized by the presence of labour unions and unemployment has been the focus of some recent papers, which show that a Pareto superior reform towards a private pension system always exists. Corneo and Marquardt (2000) show that a Pareto improving transition is possible due to the interactions of the unemployment insurance program and the public pension system. Changes on the unemployment insurance program may lower the wage rate demanded by the labour union, thereby reducing the PAYGO benefit and creating additional savings incentives which raise the rate of economic growth in such a way that there are welfare gains greater than the transition burden. On the 
other hand Demmel and Keuschnigg (2000) show that when the unemployment rate responds to changes in the policy variables a Pareto superior transition to a private funded system can be achieved because the reduction of the PAYGO system also implies a reduction in the implicit tax on labour that the PAYGO entails.

Although our analysis is inspired by these papers, we move forward in several directions. First of all, in contrast to Corneo and Marquardt (2000), we allow for the unemployment rate to depend on the policy variables. Privatizing social security directly affects the unemployment rate, labour productivity and the demand for capital. Furthermore, by allowing for a degree of intra- generational redistribution through the pension system we show that, without taking into account the implicit tax on labour, the existence of a within generation redistributive PAYGO benefit is unemployment reducing (i.e. privatization of the pension system can have adverse effects on macroeconomic variables in equilibrium). Moreover we show that even though a private pension system can be welfare improving for all future generations, when we take into account the transition cost, privatizing the pension system may be Pareto inferior ${ }^{1}$.

We model the pension benefit as a conditional benefit that is received only by those who have contributed to the system, i.e. the employed. In most countries, prolonged unemployment may lead to reduced pension benefits or extension of the working life in order to compensate for the lower contributions to the system before being eligible for the benefit. Furthermore, following Casamatta et. al. (2000), we assume that the PAYGO pension not only redistributes between generations, but also redistributes within generations in such a way that an increase on the individual wage does not lead to an exact increase in the pension benefit. The above two features of the PAYGO pension system imply that when unions bargain over higher wages they only increase the working period income, without (fully) affecting retirement income. At the same time higher wages lead to higher unemployment probability and lower probability of receiving the pension benefit. Thus the existence of a PAYGO- public pension benefit tilts the balance towards wage moderation.

In our setting the PAYGO scheme is treated as an additional benefit accrued only to the employed, giving them an incentive restraint excess wage increases. There is fairly extensive literature on the trade- off between wages and various in- job characteristics. When in- job benefits are significant, union members derive utility from being employed and exhibit wage moderation. Pension benefits may represent such in job- characteristics (Gunderson et. al., 1992), since they directly enter into the indirect utility of the workers. Furthermore it is natural

\footnotetext{
${ }^{1}$ Even if after the privatization nothing changes in the structure of the economy.
} 
to assume that once unions bargain, they do not act myopically, and maximize the life- time utility of their members.

The paper is structured as follows: in the next section we describe the model. In section 3 we show the effects of pension privatization on the macroeconomic equilibrium of the economy. Section 4 examines the welfare effects of pension privatization and the possibility of Pareto improving privatization. Finally section 5 concludes.

\section{The Model}

The model presented is a variant of Devereux and Lockwood (1991) trade union model. We consider an overlapping generations model of a small open economy with free capital mobility, perfect foresight and discrete time $t=1,2, \ldots, \infty$. In each time period there are two generations, a young which supplies inelastically its unit endowment of labour and saves for retirement, and an old retired generation with no labour endowment which consumes its accumulated wealth. The number of individuals born at time $t$ is $\mathrm{N}_{t}$ and grows at a constant rate $\mathrm{n}$ so as $\mathrm{N}_{\mathrm{t}}=\mathrm{N}_{\mathrm{t}-1}(1+\mathrm{n})$. A large and fixed number of perfectly competitive produce a homogeneous tradable good under decreasing returns to scale, with the use of capital and labour. Each individual belongs to a firm- specific trade union. In the first stage of the game the firm chooses the level of capital and afterward bargains with the union over the wage rate, i.e. we assume non- binding contracts between firms and unions (Grout, 1984). Finally the firm

unilaterally chooses the level of employment, i.e. we assume a Right- to- Manage bargaining model (Manning, 1987, Pencavel 1991).

\section{Consumers- Workers}

Consumers- workers are risk neutral and derive utility from a Cobb Douglas utility function, defined over consumption when young and old:

$$
U=c_{t}^{\delta} c_{t+1}^{1-\delta}
$$

where $c_{t}$ and $c_{t+1}$ are first and second period consumption respectively and $\delta$ is the relative weight given to the first period consumption.

Employed workers earn a net of taxes wage rate $\mathrm{w}_{\mathrm{t}}(1-\tau)$. The wage tax rate $\tau$ consists of contributions $\xi$ to the unemployment insurance and contributions $\mathrm{z}$ to the pension program, such that $\tau=\xi+z$. When unemployed, individuals receive unemployment compensation $b_{\mathrm{t}}$, where $b$ is the unemployment replacement ratio $(0<b<1)$. The income of each consumer is spent either on consumption when young or can be saved for consumption during retirement. The price of consumption is constant and normalized to 1 . Consumers can save at time t either by purchasing stocks $\theta_{t+1}$, at the price $\mathrm{q}_{\mathrm{t}}$ or by purchasing (non- depreciated) physical capital 
$\mathrm{K}_{\mathrm{t}+1}$, at the price of 1 . At retirement, consumers consume the income generated by their savings, which is equal to the return to physical capital $(1+r) K_{t+1}$ plus the return to stocks $\left(d_{t+1}+q_{t+1}\right)$, with $d_{t+1}$ the dividend per stock. Further when old, agents that were employed when young, receive a pension benefit ${ }^{2} \mathrm{P}_{\mathrm{t}+1}$.

If $l=1$ when the agent is employed at $t$ and $l=0$ otherwise, the budget constraint for each consumer is:

$$
\begin{aligned}
& c_{t}+K_{t+1}+q_{t} \theta_{t+1}=l w_{t}(1-\tau)+(1-l) b w_{t} \\
& c_{t+1}=(1+r) K_{t+1}+\left(d_{t+1}+q_{t+1}\right) \theta_{t+1}+l P_{t+1}
\end{aligned}
$$

The maximization of (1) subject to (2) and (3) yields first period consumption and savings:

$$
\begin{gathered}
C_{t}=\delta\left[l\left(w_{t}(1-\tau)+\frac{P_{t+1}}{1+r}\right)+(1-l) b w_{t}\right] \\
s_{t}=K_{t+1}+q_{t} \theta_{t+1}=(1-\delta)\left[l\left(w_{t}(1-\tau)-\frac{P_{t+1}}{1+r}\right)+(1-l) b w_{t}\right]
\end{gathered}
$$

Firms

The production function of the representative firm is:

$$
Y_{t}=A_{t} K_{t}^{\gamma} L_{t}^{\beta}
$$

where $\beta+\gamma<1$, and $A_{t}$ is the state of technology at time $t$, which is assume to grow at a constant rate $g$, i.e. $A_{t}=(1+i) A_{t+1}$.

All firm decisions are made by the owners of the firm, i.e. the stock holders. Given that we do not allow for bequests in the economy, at each time period all stocks are owned by the members of the old generation. It then follows that the objective of the stock owners is to maximize the return of the stocks. When capital markets are perfect (as it is assumed here) this is equivalent to maximizing the value of the firm.

All profits are distributed as dividends to the stock owners. Stocks are traded in the stock market, with no transactions cost. There is perfect and complete information among traders and all traders are small relative to the market. The above assumptions imply that the prices of the stocks are equal to the stream of all expected future dividends. The value of the firm will be equal to the product of total stocks outstanding times the price of each stock. If $\pi_{\mathrm{t}}$ is period $\mathrm{t}$ profits i.e.:

\footnotetext{
${ }^{2}$ Alternatively one could assume that there is a old age welfare benefit for the unemployed too. As long as this benefit is lower than the pension benefit our results do not change. For simplicity we assume that such a benefit is embodied in the unemployment benefit.
} 


$$
\pi_{t}=K_{t}^{\gamma} L_{t}^{\beta}-w_{t} L_{t}-r K_{t}
$$

then the value of each firm is given by:

$$
\Pi(t)=\pi_{t}+\sum_{i=1}^{\infty} \frac{\pi_{t+i}}{(1+r)^{i}}
$$

So in fact the goal of the firm is to maximize the stream of all future profits and thus the stock market value of the firm:

\section{Government}

$$
\max \Pi(t)=\pi_{t}+\sum_{i=1}^{\infty} \frac{\pi_{t+i}}{(1+r)^{i}}
$$

The government uses labour taxes in order to finance unemployment and pension benefits. We assume that each program has a different budget constraint, so that both programs are in balance at each time period.

The unemployment benefit is a fixed percentage $b$ of the current period wage. The unemployment compensation redistributes income from the employed to the unemployed. The balanced budget requirement for the unemployment program implies that:

$$
\xi \bar{w}\left(1-u_{t}\right) N_{t}=b \bar{w}_{t} u_{t} N_{t}
$$

where $u_{t}$ is the unemployment rate at time $t$ and $\bar{w}_{t}$ is the average wage at $t$.

Only employed individuals expect to receive the pension benefit $\mathrm{P}_{\mathrm{t}+1}$ when old. We assume that the pension benefit consists of two parts: a public- PAYGO component and a private fully funded-forced savings component, with $f$ the share of the PAYGO component. Thus at time $t$ the benefit at $\mathrm{t}+1$ for each individual follows the rule:

$$
P_{t+1}=f B\left[(1-\eta) \bar{w}_{t}+\eta w_{t}\right]+(1-f) z w_{t}\left(1+r_{t+1}\right)
$$

where B is the PAYGO pension benefit replacement ratio.

In the above benefit rule we define, following Casamatta et. al. (2000), $\eta$ to be the "Bismarckian" factor, i.e. the fraction of the PAYGO benefit that is related to own contributions. On the other hand $(1-\eta)$ is the PAYGO intra-generational redistributive component. As $\eta$ falls the link between individual pension contributions and pension benefits declines. Likewise a reduction in $\mathrm{f}$, reduces the size of the PAYGO benefit and increases the size of the private system. The private system works as forced savings- individual accounts system and there is a perfect correlation among contributions and benefits with no degree of intra-generational redistribution. 
By construction the private pension pillar is always in balance, since contributions are placed in the capital market and the pension benefit is the respective return $\mathrm{r}$. Then the public pension program is in balance if ${ }^{3}$ :

$$
f B \bar{w}_{t}\left(1-u_{t}\right) N_{t}=f z \bar{w}_{t+1}\left(1-u_{t+1}\right) N_{t+1}
$$

\section{Capital Market Equilibrium}

Since there is no uncertainty in the economy and no imperfections in the stock market, the return to stocks (dividend per share plus capital gain) will be equal to the return of physical capital, i.e. the arbitrage condition holds:

$$
1+r_{t+1}=\frac{d_{t+1}+q_{t+1}}{q_{t}}
$$

\section{Labour Market Equilibrium}

We adopt the Right-to-Manage model of bargaining (see Hart and Moutos, 1995) with nonbinding contracts between unions and firms (Grout, 1984). Alternatively we could have used the Efficient Bargain model, with the results of the analysis remaining the same ${ }^{4}$.

The decisions of the firm are made in three stages. At the first stage the firm chooses the amount of capital it wishes to employ. Afterwards it bargains with the firm specific union over wages and finally the firm unilaterally chooses the level of employment. Given the timing of events we solve the model backwards in order to find the time- consistent solution (Grout, 1984). Under the assumption of the small open economy with perfect capital mobility, the interest rate is fixed, $r$ and the economy instantaneously reaches the steady state. Therefore we can drop all time subscripts and focus only on the steady state values of the variables. Furthermore capital availability is not constraint by domestic savings and then the way the pension program is financed does not affect the capital supply. Public pensions however affect the labour market and thus indirectly the productivity of capital and eventually the demand for capital.

At the third stage of the game the firm, given $\mathrm{w}$ and $\mathrm{K}$ (as determined at the previous stages), chooses the employment level that maximizes its profits. Maximization of (8) with respect to $\mathrm{L}^{5}$ results into:

$$
w=\beta A K^{\gamma} L^{\beta-1}
$$

\footnotetext{
${ }^{3}$ In equilibrium, since all firms and all workers are identical, the wage rate will be the same for all workers. We exploit this fact when stating the budget constraint (12).

${ }^{4}$ The Right-to-Manage and the Efficient Bargain model in general equilibrium produce the same level of unemployment (Layard and Nickell, 1991).

${ }^{5}$ With no adjustment cost to capital and labour, the outcomes at $t$ do not affect the stream of future profits, which are given for the firm at.
} 
When the firm unilaterally chooses employment it equates the marginal productivity of labour with the wage rate. Then the solution to the bargaining problem (second stage) must always be consistent with(14).

The representative union maximizes the expected life-time income of its members ${ }^{6}$. The employed union members earn net of taxes wage income plus the pension benefit at retirement. The unemployed members are free to join another union and seek employment in another firm. If they cannot find a job, then they remain unemployed and receive the unemployment compensation. Then a representative union has the objective function:

$$
V=L\left[w(1-\tau)+\frac{P}{1+r}\right]+(N-L) x
$$

where $\mathrm{V}$ is the utility of the union, $\mathrm{L}$ is the number of employed members by the firm and $\mathrm{N}$ the number of employees assigned to each firm ${ }^{7}$ and $x$, the expected income of the unemployed members. Following Layard et. al. (1991) we define $x_{t}$ to be:

$$
x=(1-u)\left[w(1-\tau)+\frac{P}{1+r}\right]+u b w
$$

Workers expect to find employment in another firm with probability equal to the overall employment level in the economy $(1-\mathrm{u})$. However with probability $\mathrm{u}$ the worker remains unemployed and earns only the unemployment benefit ${ }^{8}$.

If an agreement is not reached all union members expect to earn $\mathrm{x}$. Then the fallback income if an agreement is not reached is:

$$
\bar{V}=N x
$$

Firms' objective is to maximize the present value of their profits. Each firm is allowed only to hire the workers of its union ${ }^{9}$. By the assumption that the capital choice is made prior to bargaining, the firm has rented the capital and if an agreement is not reached still has to pay the rental rate to the capital owners. However, the inability to reach an agreement at $t$ does not affect the path of capital and the structure of the bargaining in the subsequent periods ${ }^{10}$. Given the above the firm in the bargaining each period is maximizing the difference

\footnotetext{
${ }^{6}$ Given that the Cobb Douglas utility function produces a linear indirect utility function on income, utility and income maximization as goals of the union are equivalent.

${ }^{7}$ We normalize the number of firms to 1 .

${ }^{8}$ Alternative we can motivate (15), as if all workers are employed and experience during their working age unemployment spells with duration u (Summers, 1988, provides a similar explanation in an efficiency wage model of unemployment). Then the pension benefit is reduced according to the duration of the unemployment spell, whereas during unemployment instead of the wage rate the workers earn the unemployment benefit.

${ }^{9} \mathrm{By}$ assumption, there is a union attached to each firm. For a worker to move to another firm (if there is a job opening in that firm), he must join its union.

${ }^{10}$ This rests on the fact that there is no adjustment cost on capital (see Devereux and Lockwood, 1991)
} 


$$
\Pi-\bar{\Pi}=\left(K^{\gamma} L^{\beta}-w L-r K+\frac{D}{r}\right)-\left(-r K+\frac{D}{r}\right)=K^{\gamma} L^{\beta}-w L
$$

where $\bar{\Pi}$ is the profits of the firm if an agreement with the union is not reached.

Assuming a Nash bargaining solution ${ }^{11}$, the wage is obtained by maximizing:

$$
\max _{w} \Omega=\left(K^{\gamma} L^{\beta}-w L\right)^{a}\left[L\left[w(1-\tau)+\frac{P}{1+r}-x\right]\right]^{1-a},
$$

where $0<\alpha<1$ is the relative bargaining strength of the firm.

Maximizing (19) subject to (14) gives the first order condition:

$$
\left(\frac{w(1-\tau)+\frac{P}{1+r}-x}{w}\right)=\frac{(1-\alpha)(1-\beta)\left(1-f z-\xi+\frac{f \eta B}{1+r}\right)}{(1-a+\alpha \beta)}
$$

In equilibrium, because workers have the same ability and all firms produce under the same technology it follows that $w=\bar{w}$. In that case equation (20) can be solved for the equilibrium unemployment rate:

$$
u=\frac{N-L}{N}=\frac{(1-\alpha)(1-\beta)\left(1-f z-\xi+\frac{f \eta B}{1+r}\right)}{(1-a+\alpha \beta)\left(1-f z-\xi+\frac{f B}{1+r}-b\right)}
$$

Equilibrium unemployment depends on the policy parameters $(\mathrm{z}, \xi, \mathrm{f}, \mathrm{b}, \mathrm{B}, \eta)$ as well as the relative power of unions in the bargaining, 1- $\alpha$ and the share of labour in the production, $\beta$. This a quite standard solution for the unemployment rate in a union model (as for example in Layard et.al., 1991, Hart and Moutos, 1995).

Parameter B enters directly on the expression for $\mathrm{u}$. The intuition behind the result is very simple; an increase on the pension replacement ratio, B, increases the workers expected income at retirement. This increase in the retirement income is received by the workers only if they were employed when young. Then workers have then an incentive to show wage moderation, in order to reap the benefits of higher B at retirement. This turns out to reduce unemployment.

This latter effect depends crucially on the structure of the pension system, i.e. the degree that pensions are related to the individual wage rate, $\eta$, and on the relative size of the PAYGO pension component $\mathrm{f}$. For example when $\eta$ is low, then the pension benefit has a higher (positive) effect on $\mathrm{u}$. An increase in $\mathrm{w}$ increases the pension benefit only by $\eta$, while it

\footnotetext{
${ }^{11}$ It is known that a non- cooperative interpretation of the bargaining problem is compatible with Nash's solution. For example Binmore, Rubinstein and Wolinsky (1986) have demonstrated that the perfect equilibrium of the strategic two -person bargaining game can converge to the Nash's solution..
} 
increases the risk of unemployment and reduces the probability of receiving the pension benefit at retirement. This creates incentives for wage moderation. The same rationale applies when $\mathrm{f}$ changes, since in the private pension system $(f=0)$, benefits depend only on own contributions.

The above rely on a partial equilibrium intuition; an increase in $\mathrm{B}$ comes from a (permanent) increase on taxes z. However pension contributions also affect the unemployment rate. Moreover $\mathrm{f}$ also affects the unemployment rate through the reduction in the implicit labour tax. We explore this issue more in the next section where we consider the general equilibrium effects of a change in $\mathrm{f}$.

\section{Investment}

At the first stage of the game the firm chooses the amount of capital it rents from the capital owners (i.e. old age agents). The objective of the firm is to maximize profits. Profits of the firm, taking L, w as given as in equation (14), can be written as ${ }^{12}$ :

$$
\pi=(1-\beta) A K^{\gamma} L^{\beta}-r K
$$

By choosing $\mathrm{K}$ the firm equates the return to capital with the marginal productivity of capital:

$$
r=\gamma(1-\beta) A K^{\gamma-1} L^{\beta}
$$

With capital determined in (23) and the wage and employment determined in (14)and (21) we can compute total dividends per firm:

$$
d=A K^{\gamma} L^{\beta}-w L-r K=(1-\gamma)(1-\beta) A K^{\gamma} L^{\beta}
$$

From equations(13),(23) and (24) we can compute the (steady state) price of stocks $q$ as:

$$
q=\frac{d}{r}=\frac{1-\gamma}{\gamma} K
$$

Finally we can compute the returns to the PAYGO benefit from(12). Equation (21)shows that unemployment is constant and depends on the policy parameters and $\alpha, \beta$. Then the rate of growth of employment L, will be the rate of growth of population $\mathrm{n}$. Further since productivity grows at a constant rate $\mathrm{i}$, then the growth factor of wages will be $(1+g)=(1+n)^{\frac{\beta+\gamma-1}{1-\gamma}}(1+i)^{\frac{1}{1-\gamma}}$, due to the decreasing returns to scale technology. Therefore the budget constraint of the public pension program in the steady state equilibrium is:

\footnotetext{
${ }^{12}$ The objective of the firm is to maximize the present value of all future profits. The future stream of profits however do not depend on the capital chosen today, so without loss of generality we drop from (22) the present value of all future profits.
} 


$$
B=z \frac{w_{t+1} L_{t+1}}{w_{t} L_{t}}=z(1+g)(1+n)
$$

Equations (10), (14),(21), (23) and (26) determine the equilibrium endogenously determine $\mathrm{L}, \mathrm{K}, \mathrm{w}, \mathrm{b}, \mathrm{z}$. The price of stocks and the dividends are then residually determined by (24) and (25).

\section{Macroeconomic Effects of Privatization}

Within the above framework we examine the effects of privatization, i.e. reduction if $\mathrm{f}$. For the time being we ignore the fact that the PAYGO is in place and any change in f reduces the pension benefits of the current retirees. We will deal with this issue in section 4 where we examine the possibility of a Pareto improving transition to a private pension system.

A change in $\mathrm{f}$ affects the macroeconomic equilibrium through two channels. First it reduces the implicit tax rate on labour ${ }^{13}$. On the other hand a reduction in $f$ reduces the PAYGO component of the pension benefit and given $\eta$, it reduces the incentives for wage moderation that the system entails. The following equations show the effects of a change in $\mathrm{f}$ on the unemployment rate, the demand for capital, the unemployment benefit replacement ratio and the wage rate.

A change in $f$ affects the unemployment rate as:

$$
\frac{d u}{d f}=z u \Phi
$$

The effect of a change in $\mathrm{f}$ on the steady state capital then is given by:

$$
\frac{d K}{d f}=\frac{-z u \beta \Phi}{(1-\gamma)(1-u) \frac{r}{K}}
$$

whereas a change in $f$ affects $b$ as:

$$
\frac{d b}{d f}=-(b+\xi) z \Phi,
$$

and finally the effect of privatization on the wage rate is given by:

$$
\begin{gathered}
\frac{d w}{d f}=\frac{z u w(1-\beta-\gamma) \Phi}{(1-u)(1-\gamma)} \\
\text { where } \Phi=\frac{\left[b\left(1-\eta \frac{(1+g)(1+n)}{1+r}\right)-\frac{(1+g)(1+n)}{1+r}(1-\eta)(1-\xi)\right]}{\left(1-f z+\frac{f z(1+g)(1+n)}{1+r}\right)\left(1-f z-\xi+\frac{\eta f z(1+g)(1+n)}{1+r}\right)}
\end{gathered}
$$

\footnotetext{
${ }^{13}$ If the economy is dynamically efficient.
} 
The sign of all derivatives depend only on the sign of $\Phi$, the denominator of which is positive. Then $\Phi$ takes the sign of its numerator, which can be positive, zero or negative, i.e.:

$$
b\left(1-\eta \frac{(1+g)(1+n)}{1+r}\right)-\frac{(1+g)(1+n)}{1+r}(1-\eta)(1-\xi) \geq /<0
$$

The sign of (32) can be either positive or negative depending on the underlying parameters values. By construction the unemployment replacement ratio $b$ is much lower than one minus the unemployment compensation contribution, i.e. $1-\xi$, otherwise all workers will prefer being unemployed. If the economy is dynamically inefficient, i.e. the rate of population and economic growth is greater than the interest rate, then (32) is always negative. In that case the PAYGO system delivers higher returns than the capital market. This induces unions to show wage moderation in order to be eligible for the PAYGO and receive its benefits and achieve in this way higher returns than comparable investment in the capital market. Then an increase in $\mathrm{f}$ (higher PAYGO) reduces unemployment, increases capital, increases b and reduces wages. However if the economy is dynamically efficient, i.e. the rate of population and economic growth is lower than the interest rate, the sign of (32) is ambiguous. When $\eta$ is very close to one, (32) is more likely to be negative. On the other hand if the PAYGO pension benefit depends only on the wage contributions, i.e. $\eta$ is one, (32) will be positive.

To summarize the above results:

$$
\begin{aligned}
& \text { If } b\left(1-\eta \frac{(1+g)(1+n)}{1+r}\right)-\frac{(1+g)(1+n)}{1+r}(1-\eta)(1-\xi)>0 \\
& \Rightarrow \frac{d u}{d f}>0, \frac{d K}{d f}<0, \frac{d b}{d f}<0, \frac{d w}{d f}>0
\end{aligned}
$$

and vice versa.

\section{Can the Privatization Increase the Welfare of the Population?}

In the previous section we have examined the effects of privatization on the macroeconomic variables. This section explains how the welfare of the population is affected by a change in $\mathrm{f}$. Welfare effects are derived from the expected indirect utility. From the CobbDouglas utility function and the solution for $c_{t}$ and $c_{t+1}$ as well as the budget constraint of the unemployment compensation program (10) and the constraint of the pension program (26) the expected indirect utility can be expressed as:

$$
W=\kappa w L\left(1-f z+\frac{f z(1+g)(1+n)}{(1+r)}\right)
$$


where $\kappa=\delta^{\delta}[(1-\delta)(1+r)]^{1-\delta}$. Equation (34) expresses the indirect utility of a young individual and because the utility function is Cobb- Douglas it is a linear function on life- time income, i.e. $\mathrm{W}=\kappa \mathrm{I}$, where $\mathrm{I}$ is the life- time income of the young, $I=w L\left(1-f z+\frac{f z(1+g)(1+n)}{(1+r)}\right)$.

One can now easily derive the welfare effects of a change in $\mathrm{f}$ :

$$
\frac{d W}{d f}=\kappa L w z\left[\frac{\Phi\left(1-f z+\frac{f z(1+g)(1+n)}{1+r}\right)\left(\frac{-\beta-\beta(1-\gamma) r}{(1-\gamma) r}\right)}{(1-u)}-\frac{(1+r)-(1+g)(1+n)}{1+r}\right] \text { (35) }
$$

Clearly the expected welfare of the young generation drops when $f$ increases (the PAYGO pension is lower) when (32) holds. However if (32) is reversed then the effect of an increase in f on welfare can be either negative or positive depending on the underlying parameter values. The overall conclusion is that when we allow for pension benefits to affect the unemployment rate, privatization may decrease the welfare of the young generation even if the economy is dynamically efficient.

Now assume that (35) is negative, i.e. privatization (lower f) increases expected young generation welfare. Can privatizing the pension system lead to a Pareto improvement for all generations? To answer the above question assume at time $\mathrm{T}_{0}$ that we have a change on the benefit structure such that $d f<0$, where $d f$ is the change in $f$. The reduction in $f$ implies that the pension benefits of the retirees are decreased by zwLdf. To compensate for such a loss the government issues public debt equal to $\Delta_{0}$ in order to finance the pensions of the current retirees. Without loss of generality we assume that prior to $\mathrm{T}_{0}$, the government debt is zero. Then the public debt at $\mathrm{T}_{0}$ is $\Delta_{0}=-(z w L) d f$. To finance the debt the government imposes taxes on the income of the young, either employed or unemployed, with a tax rate $\mu^{14}$. Since the tax rate is equal across young individuals, by the transformation invariance axiom that the Nash bargaining solution satisfies, the wage and the unemployment rate (and all other macroeconomic variables) are not affected by the introduction of $\mu$. After the whole debt has been repaid, $\mu$ becomes zero and thereafter the young generations can reap all the gains of privatization. Total revenues then must satisfy:

$$
\mu L w \sum_{i=0}^{\infty} \frac{[(1+g)(1+n)]^{i}}{(1+r)^{i}}
$$

\footnotetext{
${ }^{14}$ The expected utility of the young generation is not affected by the introduction of $\mu$ only if the cost of the reform is born by the entire young generation (employed and unemployed), and not by the employed only.
} 
with (36) following directly from (35). The intertemporal budget constraint of the government is satisfied if the present value of the revenue (36) is equal to the present value of the debt, i.e. $\mu$ is:

$$
\mu=-Z \frac{(1+r)-(1+g)(1+n)}{(1+r)} d f
$$

The above reform scheme allows for a Pareto improvement if the gain in the expected worker income ${ }^{15}$ is higher than the taxes needed to finance the debt, i.e.:

$$
\left[\frac{\Phi\left(1-f z+\frac{f z(1+g)(1+n)}{1+r}\right)\left(\frac{\beta+\beta(1-\gamma) r}{(1-\gamma) r}\right)}{(1-u)}+\frac{(1+r)-(1+g)(1+n)}{1+r}\right]>\frac{(1+r)-(1+g)(1+n)}{(1+r)}
$$

If (38) is satisfied with equality, i.e. $\Phi=0$ and there are no employment effects of a change in $f$, then the present value of all reform gains are equal to the cost of the reform. When the privatization does not affect the unemployment rate, then privatization only transforms an implicit debt to an explicit one (Sinn, 2000). The PAYGO benefit reduction then cannot be Pareto improving as in Verbon (1988) and van Groezen et. al. (2000).

However if $\Phi>0$, then pension privatization as described here can make some generations better off without hurting the other generations. Then the reform is Pareto improving if the private system entails lower unemployment than the PAYGO system, i.e. if the expression in equation (33) is positive. The most interesting case however arises if $\Phi<0$ and the expression in (38) is positive. This can be the case if a reduction in $\mathrm{f}$ (which increases unemployment, and reducers the welfare of the young generation), results in a reduction of the implicit tax rate on income $^{16}$, which makes the second term (in brackets) in the left hand side of (38) greater than the first term (i.e. greater than the effect of $\Phi$ on welfare). In this case privatizing the pension scheme may be welfare improving for the future generations, however when we take into account the transition cost, the cost of privatization outweighs the benefits.

However some things are worth noting. Firstly in contrast to Demmel and Keuschnigg (2000) and Corneo and Marquardt (2000) the reform is not always Pareto superior to the statusquo. This is because the public PAYGO system may create incentives for wage moderation that outweigh the negative effect of the pension contributions- tax on employment. If on the other hand the wage moderating effects are lower than the negative effects of labour taxes, then a privatization scheme can be Pareto improving. Secondly the welfare effects of privatization

\footnotetext{
${ }^{15}$ The change in workers expected income from a change in $\mathrm{f}$ is given by (35) by dropping $\kappa$, due to the linearity on income of the indirect utility function.

${ }^{16}$ The second term (in brackets) on the left hand side of (38).
} 
are considered with respect to the expected utility of the young. This was done in order to have a homogeneous (at least ex ante, before the employment status has been revealed) population. If the population is divided into two groups, employed and unemployed, then a privatization policy may be difficult to construct (see Brunner, 1996 for the relevant discussion). Implicitly the model however allows us to use the expected utility in order to make welfare comparisons and at the same time be able to derive the welfare effects of privatization. The way we model unemployment is as if all workers remain unemployed for $\mathrm{u}$ of their time (see also footnote 8). Their pension benefit then is reduced according to the length of unemployment.

\section{Conclusions}

The main purpose of this paper was to show that in a second best environment with unemployment, a public pension system can be welfare superior to a private system even if the economy is dynamically efficient. To our knowledge the working of the pension system when there is unemployment is an open area for research. Even though the effects of the pension program is well evaluated in a perfect labour market (see Feldstein and Liebman, 2002), the issue is only partially addressed when unemployment in introduced into the picture ${ }^{17}$.

Further, we have shown that some of the arguments in favor of a private pension system are overturned when we allow for the level of unemployment to be affected by the type of the pension system. Privatization may affect the workings of the labour market, through the incentives for wage moderation. Reducing the size of the PAYGO system may increase or decrease the unemployment rate.

The paper also provides useful insights about the possibility of a Pareto- improving transition to a private- funded system. Even though such a policy may be Pareto improving for the young and all future generations, the cost of initiating it may outweigh the benefits. In that case privatizing the pension system may not only transform an implicit debt to an explicit one, leaving all generations (Pareto) indifferent but it may lead to a reduction of the welfare of some generations.

A final point raised in this paper is that all taxes on labour do not necessarily lead to higher unemployment. Taxes that are associated with conditional benefits to workers (like old age pension benefits) may induce wage moderation by unions. This final issue deserves more analysis, given the current interest on tax and welfare state reform (see for example Daveri and Tabellini, 2000).

\footnotetext{
${ }^{17}$ The papers by Demmel and Keuschnigg (2000) and Corneo and Marquardt (1998 and 2000) are the only exception to this statement.
} 


\section{References}

Binmore, K., Rubinstein A., and Wolinsky A., 1986. The Nash bargaining solution in economic modeling, Rand Journal of Economics 17, 176- 188.

Brunner, J. K., 1996. Transition from a pay-as- you go to a fully funded pension system: the case of differing individuals and intragenerational fairness. Journal of Public Economics $60,131-146$.

Casamatta, G., Cremer H., and Pestieau P., 2000. The political economy of Social Security, Scandinavian Journal of Economics 102, 502-522.

Corneo, G. and Marquardt, M., 2000. Public pension, unemployment insurance and growth. Journal of Public Economics 75, 293-311.

Daveri, F. and Tabellini, G., 2000. Unemployment, growth and taxation in industrial countries. Economic Policy April 2000, 47-104.

Demmel, R. and Keuschnigg, C., 2000. Funded pensions and unemployment. FinanzArchiv 57, 22-38.

Devereux, M. B. and Lockwood, B., 1991. Trade unions, non- binding wage agreements and capital accumulation. European Economic Review 35, 1411-1427.

Diamond, P.A, 1996. Proposals to restructure Social Security, Journal of Economic Perspectives 10, 67-88.

Feldstein, M. and Liebman, J. B., 2002. Social security. In: Auerbach A.J. and Feldstein, M. (Eds.), Handbook of Public Economics. Elsevier Science, Amsterdam.

Gramlich, E.M., 1996. Different approaches for dealing with Social Security, Journal of Economic Perspectives 10, 55-66.

Grout, P., 1984. Investment and wages in the absence of legally binding contracts: a Nash bargaining approach. Econometrica 52, 449-460.

Gunderson, M., Hyatt, D. and Pesando J. E., 1992. Wage- pension trade- offs in collective agreements. Industrial and Labour Relations Review 46, 146-160.

Hart R., and Moutos, T., 1995. Human capital, employment and bargaining, Cambridge, Cambridge University Press.

Holzmann, R., 1997. Pension reform, financial market development and economic growth: preliminary evidence from Chile, IMF Staff Papers 44, 149-178.

Layard, P. R. G., and Nickell, S., 1991. Is unemployment lower if unions bargain over employment, Quarterly Journal of Economics 104, 485-506. 
Layard, R., Jackman, R., and Nickell, S., 1991. Unemployment, Oxford: Oxford University Press.

Manning, A., 1987. An integration of trade union models in a sequential bargaining framework, Economic Journal 97, 121-139.

Pencavel, J., 1991. Labour markets under trade unionism: employment, wages and hours, Oxford: Blackwell.

Summers, L. H., 1988. Relative wages, efficiency wages, and Keynesian unemployment, American Economic Review 78, 383-385.

van Groezen, B., Leers, T. and Meijdam L., 2003. Social security and endogenous fertility: pensions and child allowances as Siamese twins. Journal of Public Economics 87, 233-251.

Verbon, H. A. A., 1988. Conversion policies for public pensions plans in a small open economy. In: Gustafsson, B., Klevmarken, N. A. (Eds), The Political Economy of Social Security. Elsevier Science, Amsterdam.

Sinn, H.W., 2000. Why a funded pension and why it is not useful. International Tax and Public Finance 7, 389- 410.

World Bank, 1994. Averting the old age crisis. Washington, D.C.: World Bank. 


\section{CESifo Working Paper Series}

(for full list see www.cesifo.de)

1305 Julia Darby, Anton Muscatelli and Graeme Roy, Fiscal Federalism, Fiscal Consolidations and Cuts in Central Government Grants: Evidence from an Event Study, October 2004

1306 Michael Waldman, Antitrust Perspectives for Durable-Goods Markets, October 2004

1307 Josef Honerkamp, Stefan Moog and Bernd Raffelhüschen, Earlier or Later: A General Equilibrium Analysis of Bringing Forward an Already Announced Tax Reform, October 2004

1308 M. Hashem Pesaran, A Pair-Wise Approach to Testing for Output and Growth Convergence, October 2004

1309 John Bishop and Ferran Mane, Educational Reform and Disadvantaged Students: Are They Better Off or Worse Off?, October 2004

1310 Alfredo Schclarek, Consumption and Keynesian Fiscal Policy, October 2004

1311 Wolfram F. Richter, Efficiency Effects of Tax Deductions for Work-Related Expenses, October 2004

1312 Franco Mariuzzo, Patrick Paul Walsh and Ciara Whelan, EU Merger Control in Differentiated Product Industries, October 2004

1313 Kurt Schmidheiny, Income Segregation and Local Progressive Taxation: Empirical Evidence from Switzerland, October 2004

1314 David S. Evans, Andrei Hagiu and Richard Schmalensee, A Survey of the Economic Role of Software Platforms in Computer-Based Industries, October 2004

1315 Frank Riedel and Elmar Wolfstetter, Immediate Demand Reduction in Simultaneous Ascending Bid Auctions, October 2004

1316 Patricia Crifo and Jean-Louis Rullière, Incentives and Anonymity Principle: Crowding Out Toward Users, October 2004

1317 Attila Ambrus and Rossella Argenziano, Network Markets and Consumers Coordination, October 2004

1318 Margarita Katsimi and Thomas Moutos, Monopoly, Inequality and Redistribution Via the Public Provision of Private Goods, October 2004

1319 Jens Josephson and Karl Wärneryd, Long-Run Selection and the Work Ethic, October 2004 
1320 Jan K. Brueckner and Oleg Smirnov, Workings of the Melting Pot: Social Networks and the Evolution of Population Attributes, October 2004

1321 Thomas Fuchs and Ludger Wößmann, Computers and Student Learning: Bivariate and Multivariate Evidence on the Availability and Use of Computers at Home and at School, November 2004

1322 Alberto Bisin, Piero Gottardi and Adriano A. Rampini, Managerial Hedging and Portfolio Monitoring, November 2004

1323 Cecilia García-Peñalosa and Jean-François Wen, Redistribution and Occupational Choice in a Schumpeterian Growth Model, November 2004

1324 William Martin and Robert Rowthorn, Will Stability Last?, November 2004

1325 Jianpei Li and Elmar Wolfstetter, Partnership Dissolution, Complementarity, and Investment Incentives, November 2004

1326 Hans Fehr, Sabine Jokisch and Laurence J. Kotlikoff, Fertility, Mortality, and the Developed World's Demographic Transition, November 2004

1327 Adam Elbourne and Jakob de Haan, Asymmetric Monetary Transmission in EMU: The Robustness of VAR Conclusions and Cecchetti's Legal Family Theory, November 2004

1328 Karel-Jan Alsem, Steven Brakman, Lex Hoogduin and Gerard Kuper, The Impact of Newspapers on Consumer Confidence: Does Spin Bias Exist?, November 2004

1329 Chiona Balfoussia and Mike Wickens, Macroeconomic Sources of Risk in the Term Structure, November 2004

1330 Ludger Wößmann, The Effect Heterogeneity of Central Exams: Evidence from TIMSS, TIMSS-Repeat and PISA, November 2004

1331 M. Hashem Pesaran, Estimation and Inference in Large Heterogeneous Panels with a Multifactor Error Structure, November 2004

1332 Maarten C. W. Janssen, José Luis Moraga-González and Matthijs R. Wildenbeest, A Note on Costly Sequential Search and Oligopoly Pricing, November 2004

1333 Martin Peitz and Patrick Waelbroeck, An Economist's Guide to Digital Music, November 2004

1334 Biswa N. Bhattacharyay and Prabir De, Promotion of Trade, Investment and Infrastructure Development between China and India: The Case of Southwest China and East and Northeast India, November 2004

1335 Lutz Hendricks, Why Does Educational Attainment Differ Across U.S. States?, November 2004

1336 Jay Pil Choi, Antitrust Analysis of Tying Arrangements, November 2004 
1337 Rafael Lalive, Jan C. van Ours and Josef Zweimueller, How Changes in Financial Incentives Affect the Duration of Unemployment, November 2004

1338 Robert Woods, Fiscal Stabilisation and EMU, November 2004

1339 Rainald Borck and Matthias Wrede, Political Economy of Commuting Subsidies, November 2004

1340 Marcel Gérard, Combining Dutch Presumptive Capital Income Tax and US Qualified Intermediaries to Set Forth a New System of International Savings Taxation, November 2004

1341 Bruno S. Frey, Simon Luechinger and Alois Stutzer, Calculating Tragedy: Assessing the Costs of Terrorism, November 2004

1342 Johannes Becker and Clemens Fuest, A Backward Looking Measure of the Effective Marginal Tax Burden on Investment, November 2004

1343 Heikki Kauppi, Erkki Koskela and Rune Stenbacka, Equilibrium Unemployment and Capital Intensity Under Product and Labor Market Imperfections, November 2004

1344 Helge Berger and Till Müller, How Should Large and Small Countries Be Represented in a Currency Union?, November 2004

1345 Bruno Jullien, Two-Sided Markets and Electronic Intermediaries, November 2004

1346 Wolfgang Eggert and Martin Kolmar, Contests with Size Effects, December 2004

1347 Stefan Napel and Mika Widgrén, The Inter-Institutional Distribution of Power in EU Codecision, December 2004

1348 Yin-Wong Cheung and Ulf G. Erlandsson, Exchange Rates and Markov Switching Dynamics, December 2004

1349 Hartmut Egger and Peter Egger, Outsourcing and Trade in a Spatial World, December 2004

1350 Paul Belleflamme and Pierre M. Picard, Piracy and Competition, December 2004

1351 Jon Strand, Public-Good Valuation and Intrafamily Allocation, December 2004

1352 Michael Berlemann, Marcus Dittrich and Gunther Markwardt, The Value of NonBinding Announcements in Public Goods Experiments: Some Theory and Experimental Evidence, December 2004

1353 Camille Cornand and Frank Heinemann, Optimal Degree of Public Information Dissemination, December 2004

1354 Matteo Governatori and Sylvester Eijffinger, Fiscal and Monetary Interaction: The Role of Asymmetries of the Stability and Growth Pact in EMU, December 2004 
1355 Fred Ramb and Alfons J. Weichenrieder, Taxes and the Financial Structure of German Inward FDI, December 2004

1356 José Luis Moraga-González and Jean-Marie Viaene, Dumping in Developing and Transition Economies, December 2004

1357 Peter Friedrich, Anita Kaltschütz and Chang Woon Nam, Significance and Determination of Fees for Municipal Finance, December 2004

1358 M. Hashem Pesaran and Paolo Zaffaroni, Model Averaging and Value-at-Risk Based Evaluation of Large Multi Asset Volatility Models for Risk Management, December 2004

1359 Fwu-Ranq Chang, Optimal Growth and Impatience: A Phase Diagram Analysis, December 2004

1360 Elise S. Brezis and François Crouzet, The Role of Higher Education Institutions: Recruitment of Elites and Economic Growth, December 2004

1361 B. Gabriela Mundaca and Jon Strand, A Risk Allocation Approach to Optimal Exchange Rate Policy, December 2004

1362 Christa Hainz, Quality of Institutions, Credit Markets and Bankruptcy, December 2004

1363 Jerome L. Stein, Optimal Debt and Equilibrium Exchange Rates in a Stochastic Environment: an Overview, December 2004

1364 Frank Heinemann, Rosemarie Nagel and Peter Ockenfels, Measuring Strategic Uncertainty in Coordination Games, December 2004

1365 José Luis Moraga-González and Jean-Marie Viaene, Anti-Dumping, Intra-Industry Trade and Quality Reversals, December 2004

1366 Harry Grubert, Tax Credits, Source Rules, Trade and Electronic Commerce: Behavioral Margins and the Design of International Tax Systems, December 2004

1367 Hans-Werner Sinn, EU Enlargement, Migration and the New Constitution, December 2004

1368 Josef Falkinger, Noncooperative Support of Public Norm Enforcement in Large Societies, December 2004

1369 Panu Poutvaara, Public Education in an Integrated Europe: Studying to Migrate and Teaching to Stay?, December 2004

1370 András Simonovits, Designing Benefit Rules for Flexible Retirement with or without Redistribution, December 2004

1371 Antonis Adam, Macroeconomic Effects of Social Security Privatization in a Small Unionized Economy, December 2004 